\title{
Time Allocation AND FeElings OF HAPPINESS OF SELF-EMPLOYED Persons - A Gendered Perspective
}

\author{
Miroslava Knapková ${ }^{1}$; Miriam Martinkovičová ${ }^{2}$; Alena Kaščáková ${ }^{3}$ \\ Matej Bel University, Faculty of Economics, \\ ${ }^{1,2}$ Department of Economics, \\ ${ }^{3}$ Department of Quantitative Methods and Information Systems, \\ Tajovského 10, 97590 Banská Bystrica, Slovakia \\ e-mail: ${ }^{1}$ miroslava.knapkova@umb.sk; ${ }^{2}$ miriam.martinkovicova@umb.sk; \\ 3alena.kascakova@umb.sk
}

\begin{abstract}
This article focuses on the division of the daily activities of self-employed persons on entrepreneurial activities, unpaid work, leisure time and other activities, and their interconnection to the feelings of happiness (as part of subjective well-being). Modified Time Use Survey (TUS) methodology was used to gather data on division of time and to identify SWB. The 13 groups of activities and 161 self-employed persons were included in the analysis. The results suggest that both self-employed men and women dedicate more than 8 hours per day for paid work. Daily activities during which the highest part of self-employed men and women feel the happiest belong to leisure activities. Unpaid work activities bring the highest feeling of happiness to $12.5 \%$ of self-employed women. Feelings of happiness of self-employed women are more fluctuating during the paid work than feelings of happiness of self-employed men. In the evening, the feelings of happiness of the self-employed women decrease significantly, which could be caused by double burden of self-employed women.
\end{abstract}

\section{Keywords}

Self-employed persons; Gender; Subjective well-being; Time allocation; Entrepreneurship; Daily activities.

\section{Introduction}

Increasing interest in the issue of quality of life, happiness or satisfaction has undergone an interesting and contradictory development, especially in terms of finding appropriate indicators and ways to measure them. The complexity of the issue is evidenced by the shift of theoretical reflections from the neoclassical welfare economy (Edgeworth, Marshall, Pigou), through a new welfare economy (Pareto, Hicks, Hotelling, Kaldor), towards the economy of happiness (Easterlin, Frey, Stutzer, Kahneman, Diener, Veenhoven). At the same time, there is as assumption that economic activity, the production of goods and services, is certainly not an end, but has value only if it contributes to human happiness [1]. This applies also to selfemployed persons, individuals who have voluntarily decided to devote their skills, time, and energy to achieving selected goals that they can manage themselves. As self-employment is an important part of the Slovak economy, we decided to pay attention to this issue in connection with the research of subjective well-being (SWB).

\section{$1 \quad$ Literature Review}

Satisfaction of self-employed persons has been addressed in several foreign studies. Some focus on the purely cognitive component of SWB of self-employed, such as income, wealth, 
or economic prosperity [2]. Cognitive well-being is also associated with the conditions of doing business, the organizational structure of the company, flexibility, or independence. Author of [3] examined the impact of working and family conditions on the career success and mental well-being (cognitive SWB) of 111 self-employed persons. The results of his study show that conditions in the work environment affect the time spent at work, while conditions in the family environment explain fluctuations in time spent in the home or with the family. Among SWB-related factors, he examined autonomy/independence, inflexibility of working hours, work overload, engagement at work, parental responsibilities, engagement in the family, time spent at paid work (business), conflict between work and private life, career satisfaction, family satisfaction, life stress, and other variables (especially size of business, length of business). He found that gender, work, and family characteristics (number of children, partner/spouse) significantly affect time spent at work and time spent in the family. Author of [4] extended the cognitive SWB of self-employed persons by other factors that are by nature linked to self-employment (entrepreneurship and independence, diversity of entrepreneurial activity, business life cycle, entrepreneurial health).

The affective and cognitive components of SWB are interdependent. In a sample of 122 selfemployed persons, article [5] pointed out the connection between the hedonic (affective) and cognitive components of SWB. Authors of [6] on a sample of 135 elf-employed persons from the Netherlands elaborated a classification of four determinants of SWB, namely commitment to work, job satisfaction, exhaustion and workaholism, which also cover both dimensions of SWB. According to them, these are significantly influenced by such factors as the achieved turnover, profit, and number of employees (the higher the profit and the number of employees, the happier the self-employed persons are).

Several studies point to the interrelationship between business and national happiness. Based on an analysis of available resources on entrepreneurship and SWB, study [7] found that the use of opportunities in the form of entrepreneurship contributes to societal happiness in the initial stages of entrepreneurship (in the later stages of entrepreneurship, however, this effect decreases significantly). Authors of [8] examined the impact of SWB on business in 75 European cities using data from the Quality-of-life survey. Authors of [9] focused on the impact of entrepreneurship on life satisfaction and happiness, pointing to their close connection with "national culture".

Gender is an important determinant of affective SWB of self-employed persons. Authors of [10] examined the impact of a positive emotional family background on business success in a sample of 253 entrepreneurs. They pointed out that self-employed women can combine entrepreneurship with their families and can benefit more from an emotionally positive family background better than male entrepreneurs do. Authors of [11] found those self-employed who are more educated, married and have children, are happier than other self-employed persons. They also pointed out that self-employed persons show a significantly higher average level of happiness than employees.

There are no relevant studies in Slovakia focusing on the SWB (especially affective part of SWB) of self-employed persons. We try to fulfil, at least partially, this gap.

\section{$2 \quad$ Research Subjects and Research Objectives}

This article focuses on the self-employed persons in Slovakia, their daily activities and subjective well-being expressed as the extreme (positive) emotion during the day. Selfemployment as part of small and medium sized enterprises (SME) in Slovakia belongs to the entrepreneurship (act 513/1991 Coll. Business Code) and self-employed person is a person, who gain income from business activities (act 461/2003 Coll. On Social insurance). The most 
common form of self-employment is a trade business, covering $53.75 \%$ of all economic subjects and $93.72 \%$ of self-employed persons in Slovakia (source: based on data from Statistical office SR,2020). Self-employed persons represent a specific group of respondents, mainly because the length of their paid work (entrepreneurship/business activity) is not limited by law. Self-employed persons are not under the legal protection of the Labour Code, and they can perform paid work (business activities) for any length of time on working days and even on weekends. This can have a significant effect on the amount of time spent in unpaid work and leisure activities, but also on the subjective perception of happiness.

The main objective of the article is to find out in which activities during the standard working day the self-employed men and women in Slovakia feel the happiest, it means that their affective SWB is the largest. Because of the specifics of self-employed men and selfemployed women, we focus on the daily activities and extreme positive emotion of those particular groups of self-employed persons.

Based on literature review, observation, and experience from previous research, we formulated the following research assumptions:

A1: We assume that self-employed men spend more time in paid work (entrepreneurship) than self-employed women, while self-employed women dedicate more time to unpaid work than self-employed men.

A2: We assume that the activity in which most respondents feel happy are leisure activities.

A3: We assume that the self-employed women feel happier in performing activities of unpaid work during the working day than the self-employed men.

\section{$3 \quad$ Research Methods}

To obtain information on the use of time and the affective component of SWB of selfemployed persons, we conducted an original research based on a modified TUS methodology. The survey consists of two parts, household questionnaire (concerning on socio-demographic data of households, characteristic of the household, preferences of individual members of the household), and individual time diary for every member of the household. Within the survey, we addressed 833 households in Slovakia and 1,767 individuals (household members, it means individuals were members of surveyed households).

We conducted the survey in the period of April - May 2017; with respondents reporting data for 2016 (the research was conducted as part of the VEGA project [12]). We processed the results of the survey in the second half of 2017; the first processed data were available at the beginning of 2018. To ensure the representativeness of the sample we used weights considering the population structure (based on the data from 2011 census). The dataset of households is representative according to the number of household members, and the proportion of households in the regions. Dataset of individuals is representative according to the gender and age category of the respondent.

For the purposes of this article, we further analyzed the database of individuals, specifically information about self-employed persons. Out of the total number of 1,767 respondents, there are 161 self-employed persons $(9.1 \%)$, almost $55.5 \%$ employees (in the private sector and in the public sector), $2.6 \%$ on maternity or parental leave, $1.2 \%$ unemployed, $14.8 \%$ students, $14.6 \%$ pensioners, $1.3 \%$ partially or permanently disabled persons, and $0.5 \%$ other economically inactive persons. Due to the setting of weights for the total sample, it is not possible to automatically assume the representativeness of the subset of self-employed persons according to the above characteristics. However, the survey is so original and unique 
(not only in terms of time, but also in terms of space) that we nevertheless dare to publish its results with attention to the above fact.

To find out the emotions during the performance of various activities during the day, we used one of the methods of measuring the affective component of SWB, namely the method of a time diary supplemented with the question focused on the extreme emotions. Using the question "during which activity did you feel happiest?", we were able to connect extreme (positive) emotion with a specific activity. The time diaries included 13 groups of activities belonging to the paid work, unpaid work, and leisure time, based on the HETUS 2008 classification [13]. In terms of the HETUS classification, we distinguish following activities: personal care (divided into sleeping and personal care), paid work (employment, entrepreneurial/business activity, including travelling to and from work), study and self-study, household care (divided into cleaning, childcare, and assistance to adult household members), volunteer work and social interaction, social life and entertainment, sports and other outdoor activities, leisure activities, mass media, travel and other unspecified use of time.

Table 1 shows the structure of the research sample (self-employed persons) by gender.

Tab. 1: Structure of self-employed persons by gender

\begin{tabular}{|l|l|l|}
\hline Gender & Number & Percentage \\
\hline Males & 111 & 68.7 \\
\hline Females & 50 & 31.3 \\
\hline Total & 161 & 100.0 \\
\hline
\end{tabular}

Source: Own calculations based on survey

To display information about extreme positive emotions (happiness) for 24 hours a day, we divided the day into 30-minute intervals. Even though these are relatively long intervals (a division of 10-15 minutes is used in case of official TUS [14], we consider this division to be sufficient.

\section{$4 \quad$ Results of the Research and Discussion}

Research assumption $A 1$ is based on the findings of previous research on unpaid work abroad and in Slovakia $[10,15]$. This assumption points to the fact that women, despite their duties in paid work (in our case during the performance of entrepreneurial/business activity), manage to perform a larger extent of unpaid work than self-employed men do. On the other side, we assume that self-employed men spend more time in performing business activities. On the graph in Figure 1, there are data on daily activities (divided into paid work, it means entrepreneurship, unpaid work, free time and other non-productive activities.

Results show (and confirm assumption Al) that self-employed men perform more entrepreneurial activities than self-employed women (10 hours per day comparing to 8.89 hours per day). On the other hand, self-employed women perform more unpaid work activities (2.59 hours per day, comparing to 1.17 hours per day in case of men). Self-employed men have also more time for leisure activities (3.49 hours per day, comparing to 2.77 hours in case of women). Both men and women spend more time in paid work than is the maximum working time of employees (40 hours per week, it means 8 hours per day). 


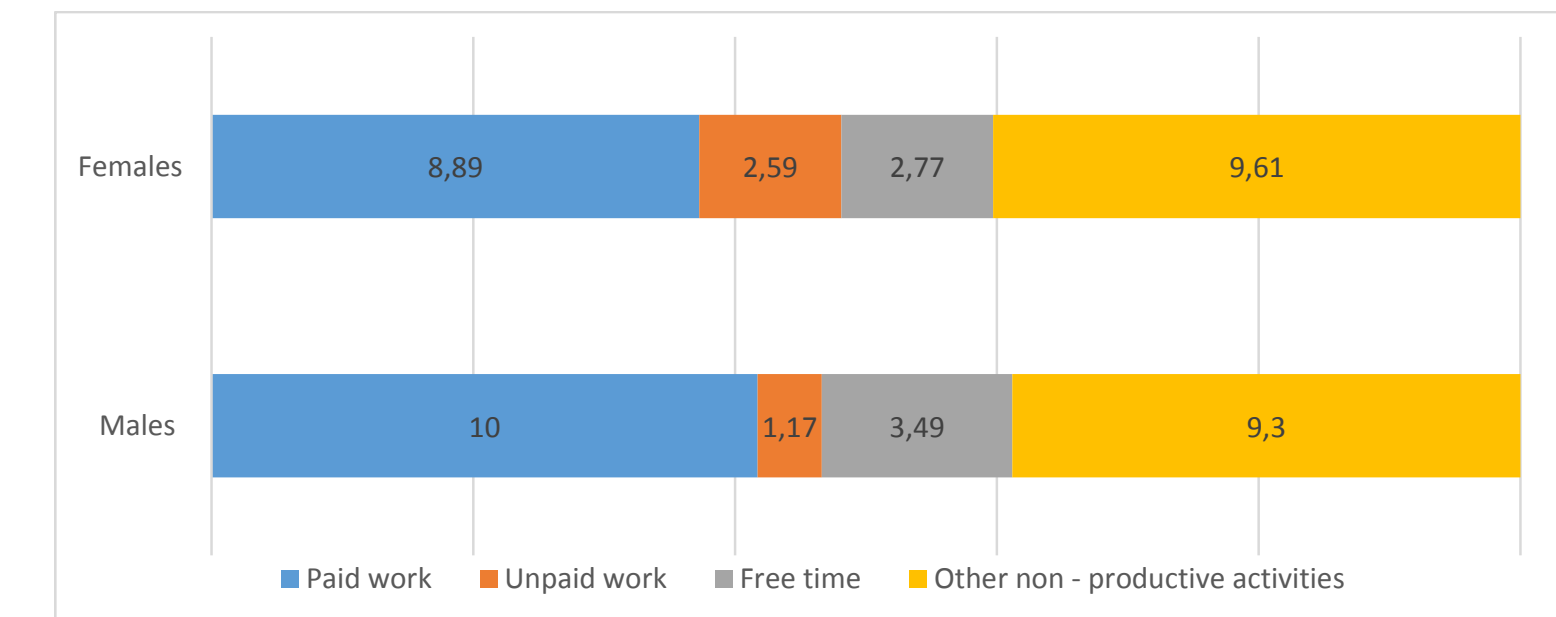

Source: $O w n$

Fig. 1: Daily activities of self-employed men and women during the working day (in hours)

Experiencing feelings is subjective, and women and men tend to feel different during the same activities. It was confirmed also for self-employed persons in several studies [16], [17]. By using the question "during which activity did you feel happiest?", we collected information about happiest moments (linked with a particular activity) of self-employed persons in Slovakia. There is information on the number of self-employed men and number of self-employed women who experienced highest happiness during various daily activities in Table 2.

Tab. 2: Daily activities and extreme feelings of happiness

\begin{tabular}{|c|c|c|c|}
\hline \multicolumn{4}{|l|}{ Men } \\
\hline & Activity & Frequency & Percent \\
\hline \multirow[t]{14}{*}{ Valid } & 1 & 7 & 6.1 \\
\hline & 2 & 3 & 2.6 \\
\hline & 3 & 2 & 2.1 \\
\hline & 4 & 17 & 15.5 \\
\hline & 5 & 1 & 0.7 \\
\hline & 6 & 2 & 1.4 \\
\hline & 7 & 11 & 9.9 \\
\hline & 8 & 0 & 0.0 \\
\hline & 9 & 41 & 37.1 \\
\hline & 10 & 6 & 5.7 \\
\hline & 11 & 10 & 9.2 \\
\hline & 12 & 6 & 5.4 \\
\hline & 13 & 1 & 0.7 \\
\hline & Total & 107 & 96.5 \\
\hline Missing & System & 4 & 3.5 \\
\hline Total & & 111 & 100.0 \\
\hline
\end{tabular}

\begin{tabular}{|l|r|r|r|}
\hline Women & \multicolumn{3}{|c|}{} \\
\hline & Activity & Frequency & Percent \\
\hline Valid & 1 & 6 & 12.0 \\
\hline & 2 & 2 & 3.2 \\
\hline & 3 & 0 & 0.0 \\
\hline & 4 & 5 & 9.5 \\
\hline & 5 & 0 & 0.0 \\
\hline & 6 & 6 & 12.5 \\
\hline & 7 & 5 & 9.3 \\
\hline & 8 & 0 & 0.0 \\
\hline & 9 & 13 & 26.8 \\
\hline & 10 & 4 & 7.8 \\
\hline & 11 & 6 & 12.6 \\
\hline & 12 & 1 & 1.6 \\
\hline & 13 & 0 & 0.0 \\
\hline & Total & 48 & 95.3 \\
\hline Missing & System & 2 & 4.7 \\
\hline Total & & 50 & 100.0 \\
\hline
\end{tabular}

Activities: 1 = sleeping, $2=$ personal care, $3=$ travelling, $4=$ paid work, $5=$ study and self-study, $6=$ household care, $7=$ childcare, $8=$ adult care, $9=$ free time - leisure activities, $10=$ free time - cultural and social activities, $11=$ free time - sport and physical activities, $12=$ free time - usage of modern technologies, $13=$ volunteer work

Source: Own 
The results show that the daily activity during which the highest part of self-employed men and women feel the happiest are leisure activities (assumption A2 was confirmed). More than $37 \%$ of men and almost $27 \%$ of women feel the strongest emotion of happiness while performing leisure activities. These activities include rest, reading books and magazines, listening to music, watching TV. The paid work (entrepreneurship) is the second most numerous group of activities in case of self-employed men (15.5\% of self-employed men feel the happiest while at paid work). Surprisingly, care for children brings the highest happiness only for less than $10 \%$ of self-employed men and self-employed women. Unpaid work activities (including food preparation, washing up, cleaning, doing the laundry, ironing, house/garden/car repair and maintenance, shopping, and dealing with authorities) brings the highest feeling of happiness to $12.5 \%$ of self-employed women, but only to $1.4 \%$ of selfemployed men (assumption A3 was confirmed).

The so-called double burden of women is a part of their lives also in case of self-employed women. Besides knowing daily activities and feeling of happiness, we were also interested in the development of the feeling of happiness during the day. There is a development of feeling of happiness of self-employed men and self-employed women during the day in Figure 2 . The figure shows time intervals on the $\mathrm{x}$-axis (from 0:00 to 24:00, divided by 30 minutes). The $y$ axis shows the shares of those self-employed persons in the total number of self-employed (divided by gender) who feel extremely positive emotion (happiness) at a given time.

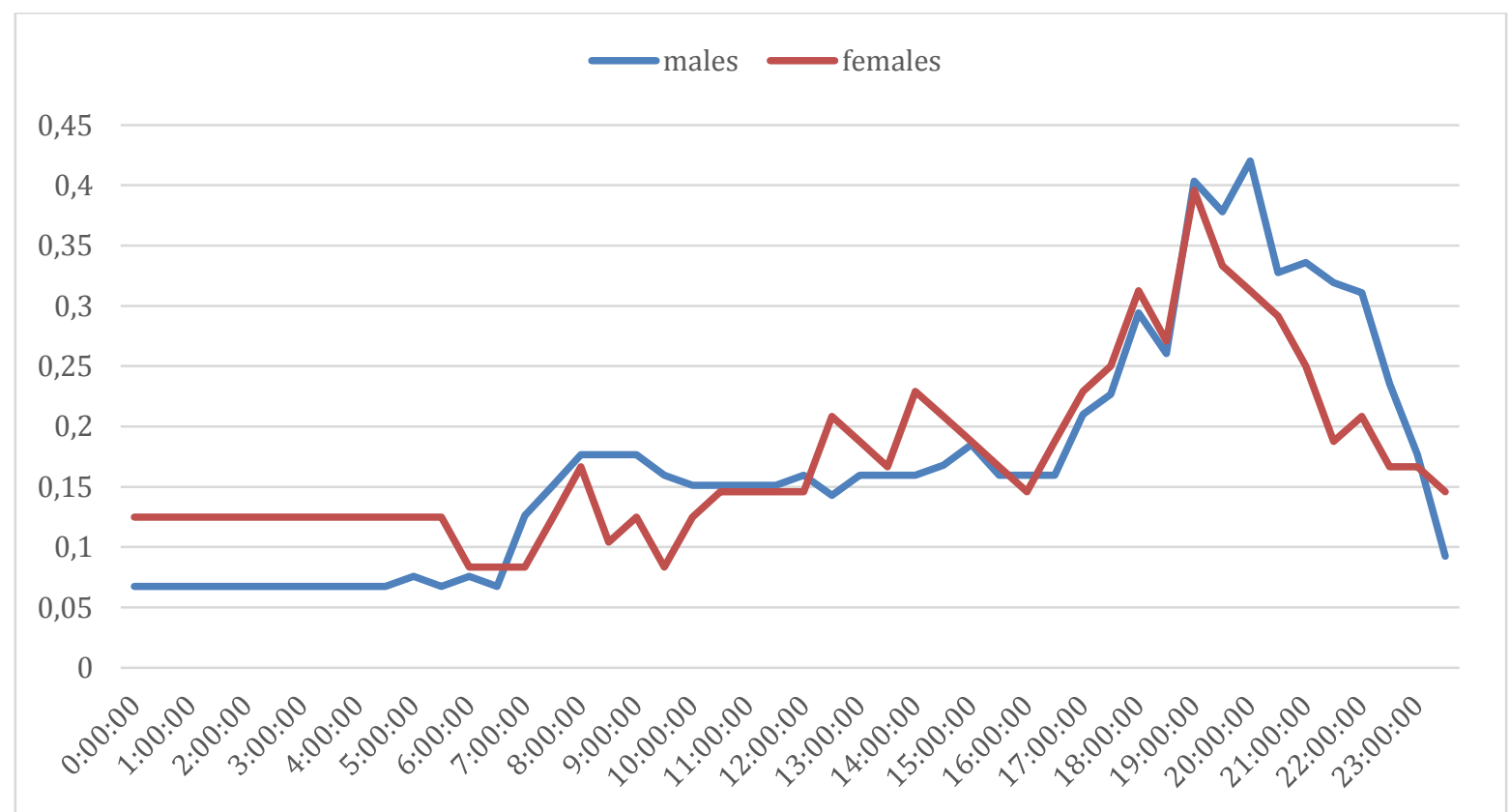

Source: Own elaboration

Fig. 2: Extreme emotion of happiness of self-employed persons, divided by gender

The graph in Figure 2 shows how the extremely positive emotions develop in different categories of self-employed persons during the day ( 24 hours). The results of the survey show that feeling of happiness of self-employed women is more fluctuating during the paid work (between the $7 \mathrm{am}$ and $4 \mathrm{pm}$ ) than feeling of happiness of self-employed men at the same time. More self-employed men feel happiest in the morning (7:00 am till 12:00 midday) than self-employed women. It could indicate higher focus on the work, not interference by morning household routines. On the other hand, more self-employed women feel happiest in the early afternoon (12 till $3 \mathrm{pm}$ ), which is still time of the paid work. It could indicate higher enthusiasm for finishing the business activity and starting other daily activities. For both, men and women, the feeling of happiness is increasing in the late afternoon and early evening 
(from 4:30 p.m. till 7 p.m.). After 7 p.m., the feelings of happiness of the self-employed women decrease significantly, compared to self-employed men (the share of self-employed women who feel extreme emotions of happiness at this time is lower than the share of selfemployed men). During the evenings, there are mainly activities that fall into the category of home and family care and free time activities. It seems that the double burden of women is so exposed in the evening that their feeling of happiness is decreasing.

This finding contradicts the results, which apply to women and men employed in the private sector. In this group of respondents (employees in the private sector), female employees show a significantly higher share of extremely positive emotions than employees do [18]. It can be concluded (however, only implicitly) that entrepreneurship and the obligations associated with business activities, irregular working hours, diverse and non-routine work activities during the day, and overall energy demanding business activities cause greater emotional exhaustion and a faster decline in positive emotions of self-employed women than of employed women.

\section{Conclusion}

Doing business means undertaking voluntarily certain level of risk and it requires a lot of energy, strength, will, and endurance. Doing business is physically, mentally, and emotionally extremely demanding. Behind the high work commitment, there are both positive and negative emotions that naturally accompany business activities. Achieved success, good market position, successful coping with competition or innovation, all this help to fulfil feelings of happiness and satisfaction.

When examining the division of time on various daily activities and affective component of SWB of self-employed persons in Slovakia, we focused on the gender that in our opinion, significantly affects not only the time devoted for various activities, but also the SWB. Using the data from original research (based on modified Time Use Survey methodology), we confirmed the assumption that self-employed men spend more time in paid work (entrepreneurship) than self-employed women, while self-employed women dedicate more time to unpaid work than self-employed men. We also confirmed that that the daily activity during which the highest part of self-employed men and women feel the happiest are leisure activities (these activities include rest, reading books and magazines, listening to music, watching TV). Results also indicate that self-employed women feel happier in performing activities of unpaid work during the working day than the self-employed men.

The research also shows interesting findings regarding the emotional stamina and intensity of the emotions experienced by self-employed women. We found out that, during the whole working day, emotional feelings in case of women are more fluctuating than in the case of men. These emotional fluctuations can be explained by a more spontaneous involvement of self-employed women in managing work responsibilities and solving work problems, considerable personal responsibility, greater empathy, more intensive social interaction with co-workers, business partners or other entities. This is reflected in their exhaustion and relatively sharp drop in positive emotions in the evening compared to men. Entrepreneurship, therefore, from the point of view of gender, causes self-employed women greater emotional discomfort than men and reduces their affective component of SWB.

The research has several limitations. First of all, the sample of self-employed persons was not representative, and it is not possible to draw generally valid conclusions. Data were collected in 2017, in the period of expansion, without any influence of Covid-19 pandemic. Pandemic could have influence not only on the changes in the work performance (such as work from home also in case of self-employed persons), possibility to continue with the 
entrepreneurship, but also subjective feelings associated to daily activities. In the future research, it is necessary to include also influence of the Covid-19 pandemic, to correlate daily activities and associated feelings with various characteristics of self-employed persons and Slovak economic environment.

\section{Acknowledgements}

This article was supported by the National Research Agency of Slovakia, project VEGA no. 1/0366/21 "Dependent Entrepreneurship in Slovakia - Reflection, Measurement and Perspectives" at the Faculty of Economics, Matej Bel University in Slovakia.

\section{Literature}

[1] FREY, B. S.; STUTZER, A. The Economics of Happiness. World Economics, Volume 3, No 1, 2002. [online]. 2002. [accessed 2021-03-18]. Available from WWW: http://bsfrey.ch/articles/365_2002.pdf

[2] CARTER, S. The rewards of entrepreneurship: Exploring the incomes, wealth, and economic well-being of entrepreneurial households. Entrepreneurship Theory and Practice, 2011, Vol. 35, Issue 1, pp. 39-55. DOI: 10.1111/j.1540-6520.2010.00422.x

[3] PARASURAMAN, S., et al. Work and family variables, entrepreneurial career success, and psychological well-being. Journal of vocational behavior, 1996, Vol. 48, Issue 3, pp. 275-300. DOI: 10.1006/jvbe.1996.0025

[4] RYFF, C.D. Entrepreneurship and eudaimonic well-being: Five venues for new science. Journal of business venturing, 2019, Vol. 34, Issue 4, pp. 646-663. DOI: $10.1016 /$ j.jbusvent.2018.09.003

[5] HAHN, V. C., et al. Happy and proactive? The role of hedonic and eudaimonic wellbeing in business owners' personal initiative. Entrepreneurship theory and practice, 2012, Vol. 36, Issue 1, 97-114. DOI: 10.1111/j.1540-6520.2011.00490.x

[6] DIJKHUIZEN, J.; VELDHOVEN, M. van; SCHALK, R. Four types of well-being among entrepreneurs and their relationships with business performance. The Journal of Entrepreneurship, 2016, Vol. 25, Issue 2, pp. 184-210. DOI: $10.1177 / 0971355716650369$

[7] NAUDÉ, W.; AMORÓS, J. E.; CRISTI, O. "Surfeiting, the appetite may sicken": entrepreneurship and happiness. Small Business Economics, 2014, Vol. 42, Issue 3, pp. 523-540. DOI: $10.1007 / \mathrm{s} 11187-013-9492-\mathrm{X}$

[8] AUDRETSCH, D. B.; BELITSKI, M. Is happiness conducive to entrepreneurship? Exploring subjective well-being-entrepreneurship relationship across major European cities. Henley Centre for Entrepreneurship, 2015. [accessed 2021-03-22]. Available from

WWW:

http://assets.henley.ac.uk.s3.amazonaws.com/legacyUploads/pdf/research/researchcentres/CFE-2015-01_Audretsch_and_Belitski.pdf

[9] TEIXEIRA, A. A.; VASQUE, R. Entrepreneurship And Happiness: Does National Culture Matter?. Journal of Developmental Entrepreneurship, 2020, Vol. 25, Issue 1, 2050007. DOI: $10.1142 / \mathrm{S} 1084946720500077$

[10] POWELL, G.N.; EDDLESTON, K.A. Linking family-to-business enrichment and support to entrepreneurial success: do female and male entrepreneurs experience different outcomes?. Journal of business venturing, 2013, Vol. 28, Issue 2, pp. 261-280. DOI: $10.1016 /$ j.jbusvent.2012.02.007 
[11] MAHADEA, D.; RAMROOP, S. Influences on happiness and subjective well-being of entrepreneurs and labour: Kwazulu-Natal case study. South African Journal of Economic and Management Sciences, 2015, Vol. 18, Issue 2, pp. 245-259. DOI: $10.17159 / 2222-3436 / 2015 / \mathrm{v} 18 \mathrm{n} 2 \mathrm{a} 8$

[12] VEGA project No.1/0621/17 "Decision-making Process of Slovak Households about Allocation of Time for Paid and Unpaid Work and Household Strategies' Impact on Selected Areas of the Economic Practice

[13] EUROPEAN COMMUNITIES. Harmonized European Time Use Surveys. 2008 guidlines. Luxembourg: Office for Official Publications of the European Communities. 2009. [accessed 2021-05-27]. Available from WW: https://ec.europa.eu/eurostat/ramon/statmanuals/files/KS-RA-08-014-EN.pdf

[14] HARMONISED EUROPEAN TIME USE SURVEYS (HETUS). Guidelines. Luxembourg: Publications Office of the European Union, 2019. [accessed 2021-03-22]. Available from WWW: https://ec.europa.eu/eurostat/documents/3859598/9710775/KSGQ-19-003-EN-N.pdf

[15] URAMOVÁ, M.; ORVISKÁ M. (eds.). Neplatená práca na Slovensku. Belianum, Banská Bystrica, 2016. ISBN 978-80-557-1158-4.

[16] GIMENEZ-NADAL, J. I.; ORTEGA-LAPIEDRA, R. Self-employment and time stress: The effect of leisure quality. Applied Economics Letters, 2010, Vol. 17, Issue 17, pp. 1735-1738. DOI: $10.1080 / 13504850903266791$

[17] Stephan, U., Li, J.; Qu, J. A fresh look at self-employment, stress and health: accounting for self-selection, time and gender. International Journal of Entrepreneurial Behavior \& Research. 2020, Vol. 26, Issue 5, pp. 1133-1177. DOI: 10.1108/IJEBR-06-2019-0362

[18] MARTINKOVIČOVÁ, M.; KNAPKOVÁ, M.; KAŠČÁKOVÁ, A. Affective wellbeing of private sector employees in Slovakia. Sociológia : časopis pre otázky sociológie $=$ Slovak Sociological Review, 2020, Vol. 52, Issue 3, pp. 273-299. DOI: $\underline{10.31577 / \text { sociologia.2020.52.3.12 }}$

Ing. Mgr. Miroslava Knapková, Ph.D.; doc. PhDr. Miriam Martinkovičová, Ph.D.;

Ing. Alena Kaščáková, Ph.D. 


\section{ALOKÁCIA ČASU A POCIT ŠŤASTIA SAMOSTATNE ZÁROBKOVO ČINNÝCH OSÔB}

\section{Z HLADISKA POHLAVIA}

Príspevok sa zameriava na rozdelenie času samostatne zárobkovo činných osôb na platenú prácu (podnikanie), neplatenú prácu, vol'ný čas a d'alšie neprodukčné činnosti a ich prepojenie na pocity št’astia (ako súčast' subjektívneho wellbeingu - SWB). Na zber údajov o alokácii času a identifikáciu SWB bola použitá modifikovaná metodika Time Use Survey (TUS). Do analýzy bolo zaradených 13 skupín aktivít a 161 samostatne zárobkovo činných osôb. Výsledky naznačujú, že samostatne zárobkovo činní muži aj ženy venujú platenej práci (podnikaniu) viac ako 8 hodín denne. Medzi činnosti, počas ktorých sa najväčšia čast' samostatne zárobkovo činných mužov a žien cíti najšt'astnejšie, patria vol'nočasové aktivity. Neplatená práca prináša najväčší pocit št’astia pre 12,5 \% samostatne zárobkovo činných žien. Pocity št'astia samostatne zárobkovo činných žien vykazujú počas platenej práce väčšiu fluktuáciu ako pocity št’astia samostatne zárobkovo činných mužov. Vo večerných hodinách pocit št'astia samostatne zárobkovo činných žien výrazne klesá, čo môže byt' spôsobené tzv. dvojitým bremenom žien.

\section{ZEITVERTEILUNG UND GLÜCKSGEFÜHLE SELBSTSTÄNDIGER PERSONEN - EINE GESCHLECHTSPERSPEKTIVE}

Der Beitrag konzentriert sich auf die zeitliche Einteilung von Selbstständigen in Erwerbstätigkeit (Unternehmertum), unbezahlter Arbeit, Freizeit und anderen nicht produktiven Tätigkeiten und deren Zusammenhang mit Glücksgefühlen (im Rahmen des subjektiven Wohlbefindens - SWB). Eine modifizierte Time-Use-Survey-Methodik (TUS) wurde verwendet, um Zeitzuweisungs- und SWB-Identifikationsdaten zu sammeln. In die Analyse wurden 13 Tätigkeitsgruppen und 161 Selbständige einbezogen. Die Ergebnisse deuten darauf hin, dass selbstständige Männer und Frauen sich mehr als 8 Stunden täglich einer bezahlten Arbeit widmen (Unternehmertum). $\mathrm{Zu}$ den Aktivitäten, bei denen sich die meisten selbstständigen Männer und Frauen am glücklichsten fühlen, zählen Freizeitaktivitäten. Unbezahlte Arbeit bringt für 12,5 \% der selbstständigen Frauen das größte Glücksgefühl. Die Glücksgefühle selbstständiger Frauen zeigen eine stärkere Fluktuation während der Erwerbstätigkeit als die Glücksgefühle selbstständiger Männer. Abends lässt das Glücksgefühl selbstständiger Frauen deutlich nach, was durch die sogenannte Doppelbelastung der Frauen hervorgerufen werden kann.

\section{ALOKACJA CZASU A POCZUCIE SZCZĘŚCIA OSÓB SAMOZATRUDNIONYCH - PERSPEKTYWA PŁCI}

W artykule skupiono się na podziale czasu osób samozatrudnionych na pracę zarobkową (działalność gospodarcza), pracę nieodpłatną, czas wolny i inne czynności nieprodukcyjne oraz ich związek z poczuciem szczęścia (będącego elementem dobrostanu subiektywnego - SWB). Do gromadzenia danych dotyczących alokacji czasu i identyfikacji SWB wykorzystano zmodyfikowaną metodykę Time Use Survey (TUS). Analizą objęto 13 grup czynności oraz 161 osób pracujących na własny rachunek. Wyniki wskazują, że samozatrudnieni mężczyźni i kobiety poświęcają więcej niż 8 godzin dziennie na pracę zarobkową (działalność gospodarczą). Czynności, podczas których większość samozatrudnionych mężczyzn i kobiet czuje się najszczęśliwsza, obejmują zajęcia rekreacyjne. Praca nieodpłatna przynosi największe poczucie szczęścia 12,5\% kobiet pracujących na własny rachunek. Poczucie szczęścia samozatrudnionych kobiet wykazuje większą zmienność podczas pracy zarobkowej niż poczucie szczęścia samozatrudnionych mężczyzn. W godzinach wieczornych poczucie szczęścia samozatrudnionych kobiet znacznie spada, co może być spowodowane tzw. podwójnym obciążeniem kobiet. 